Pobrane z czasopisma Annales I - Philosophy and Sociology http://philosophia.annales.umcs.pl Data: 26/04/2023 14:33:07

10.17951/i.2016.41.1.109

A N N A L E S

UNIVERSITATIS MARIAE CURIE-SKŁODOWSKA

LUBLIN - POLONIA

VOL. XLI, 1

SECTIO I

2016

MATEUSZ BUCZEK

Uniwersytet Marii Curie-Skłodowskiej w Lublinie

\title{
Libertariańskie poglądy na policję i sądy w ujęciu Murraya Newtona Rothbarda
}

Libertarian Views on Police and Courts of Law by Murray Newton Rothbard

Libertarianizm (ang. Libertarianism) - względnie libertaryzm - można zdefiniować jako wolnościową i skrajnie indywidualistyczną ideologię społeczno-polityczną oraz nawiązujący do jej założeń ruch polityczny, oparte o tezę, iż osnową historii jest stały i nieprzejednany konflikt pomiędzy wolnością a władzą, oraz głoszące, że każdy człowiek winien mieć nieograniczoną swobodę dysponowania swoją osobą i własnością, czyli tym, co wypracował sam albo dostał lub nabył od innych, o ile tylko nie ogranicza analogicznej swobody innych jednostek*.

\section{AKSJOMAT NIEAGRESJI I KRYTERIA DO USTALANIA}

Chcąc opisać propozycje Murraya Newtona Rothbarda, należy w pierwszej kolejności zacząć od przedstawienia naczelnej zasady, jaką kierują się popierający go libertarianie. Aksjomat nieagresji stanowi etyczny fundament libertarianizmu. Jego brzmienie wyraża się mniej więcej w postaci negatywnego imperatywu wyłączającego prawo jakiegokolwiek człowieka, działającego jednostkowo czy w grupie, do agresji skierowanej przeciwko osobie, tudzież własności drugiego człowieka. Samą agresję według Rothbarda „definiuje się jako zainicjowanie użycia lub groźbę użycia przemocy przeciwko osobie lub własności innego człowieka. Agresja jest więc synonimem naruszenia praw"1. Mowa tu nie tylko

* J. Bartyzel, Geneza i próba systematyki głównych nurtów libertarianizmu, [w:] Libertarianizm - teoria, praktyka, interpretacje, red. W. Bulira, W. Gogłoza, Lublin 2010, s. 15.

1 M.N. Rothbard, O nowa wolność. Manifest libertariański, przeł. W. Falkowski, Warszawa 2007, s. 45. 
o aktywnym naruszeniu przejawiającym się w bezpośrednich czynach, ale także o pasywnej agresji w postaci ustanawiania ograniczeń forsowanych pod płaszczem legalizmu. Naruszenie własności i zdrowia/życia jest traktowane na równi ze względu na specyficzną kategorię samoposiadania².

Powyższe założenia są punktem wyjścia i rdzeniem, wokół którego została nadbudowana cała etyka libertarianizmu. Stanowią one uniwersalne i podstawowe prawo, które jest punktem odniesienia dla innych zasad postępowania, oraz kryterium weryfikacji ich słuszności. Kryterium, branym pod uwagę przez Rothbarda przy wysuwaniu jego propozycji, jest relacja czynu do człowieka i jego własności, jak również jego egoistycznego ${ }^{3}$ interesu, traktowanych oczywiście jednostkowo, nigdy zbiorowo.

\section{PROPOZYCJE}

\section{Policja}

Ze względu na skrajnie wolnościowy i antypaństwowy charakter myśli Rothbarda, trudno jest przedstawić propozycje systemowe, a tym bardziej ustrojowe. Można jednak wyobrażać sobie, jak działałyby przedsiębiorstwa zapewniające bezpieczeństwo na wolnym rynku. Częściowo mamy możliwość obserwowania działalności takich przedsiębiorstw, np. w postaci firm ochroniarskich czy agencji detektywistycznych. Ze względu na państwowy monopol na przemoc oraz mnogość struktur policyjnych ludzie jednak rzadko korzystają z usług takich firm, zdając się na łaskę policji. Mimo że każdy obywatel płaci za działalność służb mundurowych, nie ma on żadnego wpływu na ich poczynania.

Pojawia się tutaj problem centralnego sterowania: scentralizowany rząd, znajdując się w jednym miejscu i nie mając de facto doświadczenia w zapewnia-

2 „Zazwyczaj kategorię self-ownership wywodzi się od znanego twierdzenia Johna Locke’a, iż człowiek jest posiadaczem swojej własnej osoby. Stąd częste thumaczenie tego pojęcia jako samoposiadanie ma związek z umieszczeniem tej kategorii w kontekście przyrodzonego nam prawa do dysponowania sobą i bycia właścicielem siebie. Pojęcie to więc jest brane pod uwagę w dwojakim sensie: 1) jako konieczne założenie i główny aksjomat filozofii wolnościowej; 2) jako uniwersalny fundament podmiotowości człowieka, wywodzący się z koncepcji prawa naturalnego”. Zob. P. Sikora, Kategoria self-ownership a problem podmiotowości w libertarianizmie, [w:] Libertarianizm..., s. 97.

3 Mowa oczywiście o zdrowym egoizmie, niekłócącym się z pozostałymi postulatami libertarianizmu. Taką wersję proponowała m.in. A. Rand: „W popularnym znaczeniu słowo »egoizm« jest synonimem »zła«; towarzyszy mu wyobrażenie morderczej bestii depczącej po trupach, by osiągnąć swój cel, brutala nietroszczącego się o żadną żywą istotę i niedążącego do niczego poza natychmiastowym zaspokojeniem wymyślnych zachcianek. A przecież dokładne znaczenie i podręcznikowa definicja słowa »egoizm« brzmi: »troska o własny interes«. Pojęcie to nie zawiera oceny moralnej, nie mówi, czy troska o swój interes jest dobra czy zła, nie określa też, co stanowi rzeczywisty interes człowieka. Odpowiedź na te pytania należy do etyki”. Zob. A. Rand, Cnota egoizmu. Nowa koncepcja egoizmu, przeł. J. Łoziński, Poznań 2000, s. 5. 
niu ochrony, nie dysponuje zasadnymi metodami rozdysponowywania funduszy. Jedyne co rząd wie, to fakt, że budżet jest ograniczony. Decyzje o rozdysponowaniu środków opierają się więc na tym, co wydaje się słuszne rządzącym i na ograniczeniach powodowanych biurokracją. Nie ma tutaj znaczenia, czy działania policji są skuteczne i czy odpowiadają realnym zapotrzebowaniom jednostek. Można odnieść wrażenie, że większe znaczenie ma to, że zbrojne instytucje używające siły są państwu niezbędne:

[...] zasadniczym monopolem państwa jest jego wyłączność na używanie przemocy: na usługi policyjne, siły zbrojne oraz sądownictwo - ostateczną władzę rozstrzygania sporów dotyczących przestępstw i kontraktów. Kontrola policji i armii jest szczególnie ważna, gdy idzie o egzekwowanie i zapewnienie pełni władzy należącej do państwa, wliczając w to władzę najważniejszą, jaką jest siłowe uzyskiwanie dochodu ${ }^{4}$.

Gdyby istnienie policji miało rzeczywiście na celu zapewnienie bezpieczeństwa jednostkom, to jej funkcjonowanie wyglądałoby zupełnie inaczej. Policja jest z tego powodu instytucją państwa i chroni jego interesy, a nie obywateli.

Oczywiście, według Rothbarda, sytuacja na wolnym rynku byłaby całkowicie inna - to konsument decydowałby, jakiego stopnia ochrony sobie życzy i przez jakie osoby ta ochrona miałaby być zapewniana. Pieniądze byłyby przeznaczane dokładnie na takie cele, jakich życzy sobie usługobiorca, a usługodawca nie stałby przed problemami typu, gdzie wysłać patrol czy gdzie zwiększyć ochronę, jak ma to miejsce w przypadku państwowych służb. Każdy dostawałby dokładnie to, za co płaci, gdyż wysoka efektywność i niskie koszty są podstawą konkurencyjności i osiągania zysku. Decyduje to z kolei o przetrwaniu na wolnym rynku. Firmy świadczące nierzetelne i nieopłacalne usługi szybko by eliminowały same siebie z rynku. To zasadniczy aspekt odróżniający działania sektora prywatnego i państwowego. „W sektorze prywatnym produktywność firmy mierzona jest ilością pieniędzy dobrowolnie wydanych przez konsumentów na jej produkty. W sektorze publicznym pomiaru "produktywności« rządu dokonuje się - mirabile dictu - w zależności od ilości środków, jakie wydaje!"s. Środków, które - co należy zaznaczyć - rząd zdobywa na drodze przestępstwa. Nie jest to przy tym termin zastosowany na wyrost. Zauważmy, że mamy tutaj do czynienia z podwójną moralnością ustawodawców, którzy odebranie pod przymusem cudzej własności w przypadku działań jednostki nazywają kradzieżą, natomiast dla identycznego działania, którego dopuszcza się państwo, ukuli pojęcie „opodatkowanie”.

Rothbard, wskazując jednocześnie na nieudolność państwa, postuluje - podobnie jak we wszystkich pozostałych dziedzinach życia - oddanie kwestii zapewnienia bezpieczeństwa w ręce wolnego rynku. Zauważa on, że policje, które

4 M.N. Rothbard, Etyka wolności, przeł. J. Woziński, J.M. Fijor, Warszawa 2010, s. 268-269.

5 Idem, Egalitaryzm jako bunt przeciw naturze, przeł. K. Węgrzecki, Warszawa 2009, s. 188. 
muszą zajmować się ochroną wszystkich, tak naprawdę nie są w stanie chronić nikogo. Argumentuje przy tym ${ }^{6}$, że służby te muszą ciągle rozstrzygać dylemat, które przepisy są ważniejsze. Mimo że w teorii powinny one egzekwować całość prawa, to praktycznie nie są w stanie tego robić ze względu na ograniczony budżet. Muszą skupiać się na tych przestępstwach, które aktualnie są najbardziej uciążliwe, chociaż obowiązkiem tych służb jest stanie na straży całości prawa, a nie tylko jego wybranych fragmentów.

Lekarstwem na taki stan rzeczy miałyby być według Rothbarda rozwiązania wolnorynkowe. Jego zdaniem prywatne policje zapewniłyby zakres ochrony wedle życzeń klientów. Jeśli ktoś takiej ochrony by sobie nie życzył, mógłby po prostu z niej zrezygnować - to klient decyduje o tym, czy chce korzystać z usługi, jak ma być ona świadczona oraz jaką kwotę chce na nią przeznaczyć.

Policja wolnorynkowa byłaby nie tylko skuteczna, ale też miałaby silną motywację do tego, by okazywać swoim klientom uprzejmość i powstrzymywać się od brutalnych zachowań wobec nich oraz wobec ich znajomych i interesantów (ponieważ każdy byłby jej potencjalnym klientem). Wolnorynkowy sposób świadczenia usług policyjnych zachęcałby policjantów do skutecznego działania i uprzejmości wobec klientów, a karałby postawy odbiegające od tych wzorców. Przestałoby istnieć - typowe dla każdego działania rządu - oddzielenie usługi od zapłaty za nią. Oddzielenie to oznacza, że policja - podobnie jak inne organy rządowe - otrzymuje wynagrodzenie nie od klientów płacących dobrowolnie za wybraną na konkurencyjnym rynku usługę, lecz od wszystkich płacących pod przymusem podatki.

Oczywiście nie możemy zaplanować funkcjonowania wolnego rynku (właśnie dlatego, że jest wolny). Obecnie istnieje on tylko jako hipoteza, ponieważ do tej pory nie mieliśmy możliwości obserwować społeczeństwa całkowicie niezależnego od państwa. Możemy jednak przypuszczać, że ochrona policyjna w społeczeństwie wolnościowym byłaby świadczona na zlecenie właścicieli gruntów i firm ubezpieczeniowych. Ponieważ firmy ubezpieczeniowe muszą wypłacać odszkodowania ofiarom przestępstw (nie wszystkim, lecz tym ubezpieczonym), możemy z dużą dozą prawdopodobieństwa przypuszczać, że firmy te starałyby się zapewnić ochronę policyjną w celu zmniejszenia przestępczości i kosztów związanych z wypłatami odszkodowań. Nietrudno zatem sobie wyobrazić sytuację, w której firmy ubezpieczeniowe lub inne podmioty płacą okresowe składki za usługi świadczone przez prywatną policję, a agenci ochrony zjawiają się na każde żądanie.

Konkurencja gwarantuje skuteczność, niskie ceny oraz wysoką jakość i nie ma powodu, by zakładać a priori - jak to niektórzy czynią - że utrzymywanie $\mathrm{w}$ danym rejonie geograficznym jednej policji jest absolutną koniecznością.

6 Zob. idem, O nowa wolnośćc..., s. 277-279. 
Częstym argumentem przeciw „uwolnorynkowieniu” branży usług związanych z zapewnieniem bezpieczeństwa jest problem ludzi biednych, których hipotetycznie nie stać na prywatną ochronę. Libertariańska odpowiedź Rothbarda ${ }^{7}$ na ten zarzut jest dość prosta - ochrona, tak jak każdy inny towar czy usługa, jest możliwością, jaką można zrealizować, a nie koniecznością. Mimo że potrzeba bezpieczeństwa należy do najbardziej podstawowych, to obok niej znajdziemy również takie niezbędne do życia elementy, jak żywność, mieszkanie czy choćby ubranie. Chociaż są potrzebne z oczywistych powodów (być może nawet bardziej niż potrzeba bezpieczeństwa), to jednak nie słyszy się postulatów o redystrybucji tych dóbr. Takie pomysły na ogół mają przyczepianą łatkę komunizmu, nawet przez różnych wojowników o „sprawiedliwość społeczną” czy przedstawicieli innych neoliberalno-lewicowych nurtów posiadających cechy podwójnej moralności (tj. „A - redystrybuujmy, ale B - już nie” lub „Każdy człowiek powinien mieć dostęp do X, ale bez Y sobie poradzi”).

Należy przyjąć, że pewnych osób może nie być stać na opłacenie usług ochrony. Zauważmy jednak, że nawet w obecnej sytuacji, gdzie lwia część środków generowanych przez rynek jest zagarniana przez państwo, ciągle funkcjonują organizacje charytatywne i stowarzyszenia pomocy (np. prawnej, mimo że usługi prawnicze słyną z wysokich cen). Możemy śmiało uznać, że w sytuacji braku na wolnym rynku organizmu pasożytniczego w postaci państwa, o wiele większa ilość środków byłaby przekazywana na pomoc mniej zamożnym, jednocześnie zwiększając ilość środków posiadanych przez najbiedniejszych ze względu na brak podatków. Należy też zwrócić uwagę na bardzo istotną kwestię zapłaty. Usługi policyjne nie są przecież „darmowe”. Płacą za nie podatnicy, którymi często są osoby ubogie. Jest wielce prawdopodobne, że ubodzy płacą obecnie więcej na policję w podatkach, niż płaciliby w postaci rachunków za usługi prywatnych, znacznie skuteczniejszych firm. Wynika to z konieczności opłacenia armii urzędników, którzy dokonują redystrybucji. Co więcej, opłaty są przymusowe, a nie dobrowolne, jak w przypadku usług wolnorynkowych.

Wśród ludzi, którzy zetknęli się z pomysłem prywatnej ochrony policyjnej, pojawia się czasem teza o możliwości chaosu, który powstałby wskutek wiecznych konfliktów między poszczególnymi firmami świadczącymi usługi policyjne. Boją się oni, że doprowadziłoby to do ,anarchii” i tego, że ludzie wzywaliby „swoją" policję przeciwko policji „,innych”, rywalizujących z nimi osób.

Rothbard, chcąc odeprzeć ten zarzut, odwołuje się do stworzonego przez siebie przykładu:

By uniknąć emocji, odwołajmy się do przykładu hipotetycznych krain: „Rurytanii” i „Walldavii”. Zarówno Rurytanię, jak i Walldavię zamieszkują libertariańskie społeczeństwa nieposia-

7 Zob. ibidem, s. 280. 
dające rządów, z mnóstwem prywatnych podmiotów, firm i agencji policyjnych. Jeśli w ogóle dochodziłoby do jakichkolwiek konfliktów, to miałyby one zasięg lokalny, a ilość i niszcząca siła użytej w nich broni byłaby z konieczności ograniczona. Przypuśćmy, że w pewnym mieście Rurytanii dochodzi do konfliktu i strzelaniny między dwiema agencjami policyjnymi. Przynajmniej nie mogą one zastosować bombardowań ani posłużyć się bronią jądrową lub biologiczną, ponieważ spowodowałyby eksterminację własnych szeregów. Do zniszczeń na wielką skalę prowadzi podział na wielkie jednostki terytorialne z monopolistycznym rządem, bo dopiero wówczas jedyny, monopolistyczny rząd Walldavii staje do walki z odwiecznym przeciwnikiem, rządem Rurytanii - i każda ze stron może użyć broni masowej zagłady, z bronią jądrową włącznie. Wtedy bowiem straty dotknęłyby tylko „drugiej strony”, „obcego kraju”. Ponadto obecnie każdy człowiek - jako poddany monopolistycznego rządu - utożsamiany jest na zawsze przez rządy innych krajów z ,jego" rządem. Obywatela Francji utożsamia się z ,jego" rządem i jeśli inny rząd zaatakuje Francję, to zaatakuje również wszystkich jej obywateli, a nie tylko rząd Francji. Tymczasem gdy firma A prowadzi bitwę z firmą B, najgorsze, co się może wydarzyć, to wciągnięcie ich klientów do tego konfliktu, ale nikogo poza tym ${ }^{8}$.

Gdyby zatem nawet do takowej wojny doszło, to skutki konfliktu byłyby nieporównywalnie mniejsze niż w przypadku, gdy stronami konfliktu są państwa im większe terytorialnie, tym gorzej dla obywateli.

Nie ma jednak powodu, by przyjmować, że wystąpienie takiej „,anarchii” jest prawdopodobne. Zakładanie, że policje byłyby pogrążone w nieustannych konfliktach i walkach, jest absurdem, ponieważ lekceważy fakt, że taki rozwój wypadków miałby zgubny wpływ na wyniki finansowe wszystkich firm policyjnych. Takie wojny i spory byłyby niekorzystne dla interesów, dlatego na wolnym rynku agencje policyjne dbałyby o to, żeby do konfliktów nie dochodziło, a wszelkie różnice zdań byłyby rozstrzygane w prywatnych sądach, przez prywatnych sędziów lub sędziów polubownych.

Konflikty, o ile w ogóle, występowałyby niezwykle rzadko, gdyż każdy miałby swoich strażników. W praktyce w życiu codziennym niewiele byłoby okazji do bezpośrednich konfliktów między agencjami ochrony. Sposób, w jaki funkcjonują agencje ochrony czy prywatne policje ma więcej wspólnego z pewnego rodzaju ubezpieczeniem niż - jakby mogło się niektórym wydawać - osobistą małą armią.

\section{Sądy}

Zagadnienia dotyczące ochrony policyjnej prowadzą do równie ważnej problematyki związanej z ochroną, jaką są usługi sądownicze. Celem jest zapewnienie możliwie najlepszych metod sądzenia, które będą zgodne z ogólnie przyjętymi procedurami i które pozwolą na wskazanie - w przypadku dowolnego przestępstwa i sporu - kto jest przestępcą lub kto złamał umowę.

8 Ibidem, s. 281-282. 
Wiele osób, nawet wśród tych, które dopuszczają możliwość prywatnego rynku konkurencyjnych usług policyjnych, opowiada się jednak przeciwko pomysłowi całkowicie prywatnych sądów. Jak miałyby być zorganizowane sądy prywatne? Jakimi środkami dysponowałyby sądy w świecie pozbawionym państwa i rządu? Czy nie wynikłyby z tego niekończące się konflikty i „,anarchia”?

Spójrzmy najpierw na to, co oferują sądy państwowe. Przede wszystkim monopolistyczne sądy napotykają te same problemy, co wszelkie inne instytucje rządowe. Są tak samo nieskuteczne i tak samo pogardzają konsumentem. Na przykład wiadomo, że sędziowie są wybierani na swoje stanowisko nie dlatego, że są mądrzy, uczciwi i sprawnie obsługują klientów, lecz często są dyspozycyjni wobec polityków i są wybierani według kryteriów politycznych. Oprócz tego sądy są monopolami. Rozważmy hipotetycznie sytuację, że w jakimś mieście sądy są skorumpowane, przekupne, nieskuteczne i opresyjne. Wtedy hipotetyczny obywatel nie ma od nich ucieczki, ponieważ jest niejako „przydzielony” do sądu ze względu na miejsce zameldowania ${ }^{9}$ czy miejsce wydarzenia, którego sprawa dotyczy.

Rothbard przewiduje, że w społeczeństwie wolnościowym będzie wiele sądów i sędziów, którym obywatel będzie mógł powierzyć swoją sprawę. W tym przypadku również nie ma powodu, by zakładać, że mamy do czynienia z ,naturalnym monopolem" na mądrość sądowniczą.

Na podnoszony - jak zwykle w kwestiach prywatyzacji - argument finansowy Rothbard odpowiada:

Jest wiele możliwości. Każdy mógłby płacić miesięczny abonament za usługi sądowe i skorzystać z nich w potrzebie. Albo - ponieważ usług sądów potrzebowano by zapewne rzadziej niż policji - mógłby wnosić opłatę w momencie złożenia pozwu, a następnie otrzymać jej zwrot od przestępcy lub osoby winnej złamania umowy. Jeszcze innym rozwiązaniem byłoby wnoszenie opłat przez agencje ochrony, które składałyby wnioski o rozstrzygnięcie sporów. Mogłyby też powstawać przedsiębiorstwa „usług zintegrowanych”, zapewniające obsługę zarówno policyjną, jak i sądową. [...] O tym, które z tych metod byłyby najwłaściwsze, decydowałby wyłącznie rynek ${ }^{10}$.

Pojawia się także pytanie, w jaki sposób działałyby sądy w wolnościowym społeczeństwie. W szczególności - jak byłyby egzekwowane ich wyroki? Tym bardziej, że musiałyby przestrzegać nadrzędnej libertariańskiej zasady, że nie wolno używać siły wobec osoby, która nie została uznana za przestępcę.

Gdyby policja lub sądy łamały tę zasadę, to same byłyby uznane za napastników, jeśliby się okazało, że osoba, wobec której użyto siły, jest niewinna. W przeciwieństwie do obecnie panujących zasad żaden policjant ani sędzia nie miałby specjalnego immunitetu pozwalającego mu na użycie siły w zakresie przekracza-

9 Obowiązek meldunkowy ma być, co prawda, w Polsce zniesiony, lecz sądy nadal funkcjonują na podstawie właściwości miejscowej.

${ }_{10}$ M.N. Rothbard, O nowa wolnośćc..., s. 284-285. 
jącym granice obowiązujące każdego innego członka społeczeństwa. Wykonywanie jakiegokolwiek zawodu nie legitymizuje przyznania człowiekowi żadnego prawa ponad te, którymi dysponują powszechnie inne jednostki.

\section{PRAWO - PODSTAWA DO ORZEKANIA I KODYFIKACJA}

W wolnościowym społeczeństwie konieczne będzie ustalenie moralnie słusznej kodyfikacji prawnej. Czy jest możliwy kodeks prawny bez rządu, który by go ogłosił i który wyznaczyłby sędziów lub powołał władzę ustawodawczą do opracowania przepisów? W jaki sposób pogodzić ideę kodyfikacji prawnej z libertariańskimi zasadami?

Trzeba jasno stwierdzić, że kodyfikacja byłaby niezbędna do określenia ogólnych zasad, którymi powinny kierować się prywatne sądy. [...] Kodeks zawierałby po prostu libertariańską zasadę zabraniającą naruszania nietykalności osobistej i własności, określałby prawa własności zgodnie z pryncypiami wolnościowymi, ustalałby reguły dopuszczania dowodów (podobne do obowiązujących obecnie) w postępowaniu zmierzającym do wskazania winnych oraz wyznaczałby maksymalne kary dla poszczególnych przestępstw. Poruszając się w obrębie takich ustaleń kodeksowych, sądy konkurowałyby między sobą, stosując najbardziej skuteczne procedury; rynek decydowałby, które z tych procedur - sądy, sądy przysięgłych itd. - zapewniają najlepszą obsługę w dziedzinie wymiaru sprawiedliwości ${ }^{11}$.

Taki kodeks praw jest jak najbardziej możliwy. Najlepsze elementy obecnego systemu prawnego zostały wypracowane z biegiem czasu właśnie w taki sposób. To właśnie życie codzienne i ludzkie działanie wskazałyby najlepsze rozwiązania, które przechodzilyby przez utylitarystyczno-pragmatyczne sito praktyki.

Tak jak oddzielona została religia od państwa (i jak należy oddzielić od niego gospodarkę), tak też można uczynić z każdym innym aspektem działalności państwa, nie wyłączając policji, sądów i samego prawa, zwłaszcza że sądy i państwo nie respektują prawa obiektywnego. Rothbard w jednym ze swoich artykułów napisał:

Obiektywne prawo istniało na długo przed rządem (np. w postaci common law, lex Mercatora czy admiralty law) i było egzekwowane przez prywatnych, konkurujących ze sobą sędziów na długo przed wprowadzeniem państwowego monopolu. Ponieważ prawo jest obiektywne, można je odkryć za pomocą rozumu i nie potrzeba rządu, by je sformułować - wręcz przeciwnie, wielce nieprawdopodobne jest, by rząd, poddany kaprysom i zachciankom legislatorów, respektował prawo obiektywne $[\ldots]^{12}$.

Owym obiektywnym kodeksem byłoby libertariańskie prawo zakazujące agresji przeciwko jednostkom i ich własności. Taki kodeks, rzecz jasna, musiał-

11 Ibidem, s. 290.

12 Idem, On Punishment: Two Comments and a Reply, "Libertarian Forum" 1972, Vol. 4, No. 1, s. 8. 
by również definiować, czym jest własność oraz określać metody pozwalające stwierdzić, kto jest przestępcą i jak należy go wtedy traktować. Kodeksu takiego musiałyby przestrzegać nie tylko obecne na wolnym rynku sądy, ale i agencje ochrony. Jednostki i organizacje, które naruszyłyby kodeks, chcąc narzucić własne reguły, zostałyby uznane za inicjatorów agresji jednocześnie łamiące kodeks.

Ku obiektywnemu ujęciu prawa skłaniał się też znany ze swych anarchistycznych poglądów Lysander Spooner, który będąc zwolennikiem praw naturalnych, sprzeciwiał się nawet konstytucji, twierdząc:

Konstytucja nie ma przyrodzonej władzy ani sama $z$ siebie nie jest zobowiązująca. [...] Co więcej, wiemy z historii, że ta kwestia była konsultowana jedynie z niewielką grupą osób żyjących wówczas; że niewiele $\mathrm{z}$ nich było w tej kwestii pytanych o zdanie i miało prawo do wyrażenia zgody lub niezgody w sposób formalny. Te osoby, które formalnie wyraziły zgodę, już nie żyją. Większość z nich zmarło [...], a konstytucja jako umowa między nimi zmarła razem z nimi ${ }^{13}$.

Dla libertarian wszelkie inne prawa (oprócz powszechnych praw podstawowych) dotyczą zatem jedynie stron, które na te prawa przystały w drodze zawarcia dobrowolnych umów.

Rothbard w jednym ze swoich artykułów proponował, by kodeks prawny wolnego społeczeństwa oscylował wobec centrum, jakim jest libertariański aksjomat nieagresji, czyli zakaz stosowania przemocy przeciwko osobie lub jej własności z wyjątkiem sytuacji, w której trzeba bronić analogicznego dobra. Jeśli zaś chodzi o kategorię własności, to należałoby w jej zakresie uwzględnić samoposiadanie, jak również zasoby, które owa osoba znalazła, przekształciła, kupiła lub otrzymała w podarunku.

Wszelkie pozostałe przepisy kodeksu byłyby po prostu implikacjami aksjomatu nieagresji - oczywiście przepisy obecnego prawa spełniające kryterium także mogłyby zostać dołączone. Kodeks ten byłby stosowany przez wolnorynkowych sędziów przy rozpatrywaniu konkretnych przypadków. Sami sędziowie też musieliby go przestrzegać ${ }^{14}$.

\section{PODSUMOWANIE}

Na podstawie powyższej analizy można śmiało wysunąć tezę, że likwidacja państwa i rządu oraz zwrócenie ludziom prawa do decydowania o sobie wcale nie muszą oznaczać „końca świata”. Wręcz przeciwnie - uwolnienie od przymusu i ponowne zorientowanie na wolność i własność, chronione powszechnym prawem, które jest proste i jednakowe dla wszystkich, pozwala funkcjonować

${ }^{13}$ L. Spooner, Nie zdrada, przeł. S. Sękowski, Lublin 2008 (prwdr. 1870), s. 41.

${ }_{14}$ M.N. Rothbard, Interwencjonizm, czyli władza a rynek, przeł. R. Rudowski, Warszawa 2009, s. 12. 
w społeczeństwie, w którym konflikty zanikają zamiast powstawać. W przypadku, gdy jedynym zwierzchnikiem nad jednostką jest ona sama, wolność może być realizowana, a własność pozostaje nienaruszona.

Wymogiem, jaki wszyscy muszą spełnić, jest akceptacja prawa powszechnego i jego aksjomatyczności. Wydaje się to być niewielką ceną w zamian za życie w społeczeństwie, które nie zna agresji czy kradzieży, a jeśli już do takowych dojdzie, potrafi się przed nimi skutecznie bronić i z nimi walczyć.

Oferta życia w wolnym społeczeństwie przedstawiona przez Rothbarda jest propozycją wartą rozważenia. W czasach nieustannie zwiększanej kontroli ze strony opresyjnego państwa i ciągłego nakładania ograniczeń dobrze jest poświęcić chwilę refleksji temu, co jest jednym z najważniejszych wyróżników człowieka wśród innych bytów - wolności.

\section{BIBLIOGRAFIA}

Bartyzel J., Geneza i próba systematyki głównych nurtów libertarianizmu, [w:] Libertarianizm teoria, praktyka, interpretacje, red. W. Bulira, W. Gogłoza, Lublin 2010.

Rand A., Cnota egoizmu. Nowa koncepcja egoizmu, przeł. J. Łoziński, Poznań 2000.

Rothbard M.N., Egalitaryzm jako bunt przeciw naturze, przeł. K. Węgrzecki, Warszawa 2009.

Rothbard M.N., Etyka wolności, przeł. J. Woziński, J.M. Fijor, Warszawa 2010.

Rothbard M.N., Interwencjonizm, czyli władza a rynek, przeł. R. Rudowski, Warszawa 2009.

Rothbard M.N., O nowa wolność. Manifest libertariański, przeł. W. Falkowski, Warszawa 2007.

Rothbard M.N., On Punishment: Two Comments and a Reply, "Libertarian Forum" 1972, Vol. 4, No. 1.

Sikora P., Kategoria self-ownership a problem podmiotowości w libertarianizmie, [w:] Libertarianizm - teoria, praktyka, interpretacje, red. W. Bulira, W. Gogłoza, Lublin 2010.

Spooner L., Nie zdrada, przeł. S. Sękowski, Lublin 2008 (prwdr. 1870).

\section{SUMMARY}

In this article were presented proposals of Murray Newton Rothbard, one of the main representatives of libertarianism, on the police and the courts - services which are regarded by many as necessary to maintain within the equally necessary - in their opinion - the state. As we know, the state does not have its own money, in addition to those taken from their citizens by force in the form of taxes. Rothbard solutions are thus intended to prevent coercion, both on the side of using the services and those who provide these services. Due to the nature of libertarian ideas, which are characterized by simplicity and a strong emphasis on the element of freedom, this article is contained in the short form and does not indicate the specific imperatives of action.

Keywords: libertarianism; Rothbard; police; courts of law; philosophy of politics; social philosophy; etics; free market

\section{STRESZCZENIE}

W artykule zostały przedstawione propozycje Murraya Newtona Rothbarda - jednego z głównych przedstawicieli libertarianizmu - na temat policji i sądów, czyli służb, które przez wielu są 
Pobrane z czasopisma Annales I - Philosophy and Sociology http://philosophia.annales.umcs.pl Data: 26/04/2023 14:33:07

uważane jako konieczne do utrzymywania porządku w ramach równie koniecznego - ich zdaniem - państwa. Jak wiadomo, państwo nie posiada własnych pieniędzy, oprócz tych, które przymusem odbiera obywatelom w postaci podatków. Rozwiązania Rothbarda mają za zadanie uniknąc przymusu zarówno po stronie korzystających z usług, jak i tych, którzy te usługi świadczą. Ze względu na charakter libertariańskich poglądów, które cechuje prostota i silny nacisk na element wolności, artykuł ten zawiera się w krótkiej formie i nie wskazuje konkretnych imperatywów działania.

Słowa kluczowe: libertarianizm; Rothbard; policja; sądy; filozofia polityczna; filozofia społeczna; etyka; wolny rynek 